\title{
PENGARUH MODEL PEMBELAJARAN SILENT DEMONSTRATION TERHADAP KEMAMPUAN MENULIS TEKS PROSEDUR SISWA KELASVIII SMP BUDI MURNI 3 MEDAN
}

\author{
Melvianus Gulo ${ }^{1}$, Losten Tamba ${ }^{2}$ \\ *1. Penulis \\ *2. Pembimbing \\ Program Studi Pendidikan Bahasa Indonesia,FakultasKeguruan dan Ilmu Pendidikan, Universitas Katolik Santo \\ Thomas, Jl. Setia Budi No. 479-F Tanjung Sari Medan - Kode Pos No. 20132, email-melvianusgulo@gmail.com
}

Abstrak

Penelitian ini bertujuan untuk mengetahui pengaruh penggunaaan model pembelajaran silent demonstration terhadap kemampuan menulis teks prosedur. Penelitian ini dilakukan di SMP Budi Murni 3 Medan pada bulan Mei 2017. Subjek penelitian ini berjumlah 60 siswa. Metode yang digunakan dalam penelitian adalah metode eksperimen static group comparison design yang dilaksanakan pada dua kelompok. Instrumen yang digunakan untuk menjaring data adalah tes essai dalam bentuk penugasan yaitu menuliskan teks prosedur. Pengujian hipotesis dilakukan dengan menggunakan uji " $\mathrm{t}$ ". Berdasarkan hasil pengolahan data statistik yang menunjukkan bahwa kemampuan menulis teks prosedur dengan menggunakan model pembelajaran silent demonstration termasuk dalam kategori baik dengan nilai rata-rata 78.63. Sedangkan kemampuan menulis tanpa menggunakan model pembelajaran silent demonstration termasuk dalam kategori cukup dengan nilai rata-rata 61.80. Selanjutnya, pengujian hipotesis menunjukkan $t_{\text {hitung }}$ adalah 6.27 kemudian dikonsultasikan dengan tabel t pada taraf signifikan $\alpha=0.05$ dengan $\mathrm{dk}=58$ adalah 2.01. Oleh karena $t_{\text {hitung }}$ yang diperoleh lebih besar dari $t_{\text {tabel }}$ yaitu 6.27> 2.01 maka terbukti bahwa hipotesis nihil $\left(\mathrm{H}_{0}\right)$ ditolak dan hipotesis alternatif $\left(\mathrm{H}_{a}\right)$ diterima. Maka, dapat disimpulkan bahwa model pembelajaran silent demonstration berpengaruh signifikan terhadap kemampuan menulis teks prosedur siswa kelas VIII SMP Budi Murni 3 Medan tahun pembelajaran 2016/2017. Implikasi penelitian ialah siswa lebih mudah dalam menulis teks prosedur melalui peragaan yang sedikit penjelasan dari guru (bisu). Peneliti menyarankan bahwa kemampuan menulis teks prosedur perlu ditingkatkan melalui model yang sesuai.

Kata Kunci: model silent demonstration, menulis, teks prosedur.

\begin{abstract}
This study aims to know the effect of the use of silent demonstration method in the ability to write procedure text. This research was conducted in SMP Budi Murni 3 Medan in May 2016. The subject of this study numbered 60 students. The method used in this study is an experimental method static comparison group design conducted in two groups. The instrument used to collect the data is in the form of a test essay assignment that is writing the procedure text. Hypothesis testing is done by using test " $\mathrm{t}$ ". Based on the results of processing statistical data showing that the ability to write back in the news with the use of silent demonstration method included in good category with an average value of 78,63 . While the ability to write the procedure text without using the silent demonstration method included in the category enough with the average value of 61,80 . Furthermore, the hypothesis test shows is 6,27 later consulted with t table at significant level $\alpha=0,05$ with $\mathrm{dk}=58$ is 2,01 . There fore that is greater than that $6,27>2,01$ it is evident that the null hypothesis $\left(H_{0}\right)$ is rejected and the alternative hypothesis $\left(H_{a}\right)$ is received. So, it can be concluded that the silent demonstration method is effective significantly in writing the procedure text by eighth grade students of SMP Budi Murni 3 Medan in the academic year of 2016/2017. The implication of the research was the students easier in writing the procedure text
\end{abstract}


through silent demonstration method. Writer did suggest that the ability to write the procedure text needs to be improved through appropriate method.

Keywords: Effect, Silent Demonstration Method, Writing, Procedure Text.

\section{PENDAHULUAN}

Bahasa sangat penting bagi kehidupan manusia. Dengan itu, dapat dikatakan bahasa berfungsi sebagaai suatu alat yang digunakan untuk menyampaikan informasi. Secara umum keterampilan berbahasa mencakup empat aspek, yaitu keterampilan menyimak (listening skills), keterampilan berbicara (speaking skills), keterampilan membaca (reading skills), dan keterampilan menulis (writing skills). Tentu saja keempat keterampilan tersebut merupakan suatu kesatuan yang tidak dapat dipisahkan.

Keterampilan menulis merupakan salah satu jenis keterampilan berbahasa yang harus dikuasai siswa. Tarigan (2008:3) dalam kegiatan menulis ini, penulis haruslah terampil memanfaatkan grafologi, struktur bahasa, dan kosa kata. Salah satu keterampilan menulis yang dipelajari dalam mata pelajaran bahasa Indonesia adalah menulis teks prosedur di samping jenis karangan yang lainnya (fabel, biografi, diskusi, dan ulasan). Menulis teks prosedur merupakan salah satu indikator pencapaian dalam pembelajaran bahasa Indonesia di kelas VIII SMP sesuai kurikulum 2013.

Pada kenyataannya, siswa belum mampu menulis teks prosedur dengan baik. Banyak faktor yang mempengaruhi kemampuan siswa dalam menulis teks prosedur, seperti, sikap siswa yang tidak mau tahu terhadap materi pembelajaran, media pembelajaran yang masih kurang digunakan oleh pendidik, jadwal pembelajaran yang tidak mendukung, kurangnya minat siswa dalam mempelajari materi menulis teks prosedur dan metode yang digunakan guru masih bersifat konvensional (penjelasan, penugasan dan evaluasi).

Berdasarkan permasalahan yang telah dipaparkan di atas, maka penulis tertarik menjadikan permasalahan tersebut sebagai topik yang akan diteliti oleh penulis. Adapun topik yang dipilih sesuai dengan permasalahan tersebut yaitu "Pengaruh Model Pembelajaran Silent Demonstration terhadap Kemampuan Menulis Teks Prosedur Siswa Kelas VIII SMP Budi Murni 3 Medan Tahun Pembelajaran 2016/2017'.

\section{Kajian Teori \\ Pengertian Model}

Secara sederhana model dapat dipahami sebagai kerangka dasar suatu bentuk. Menurut Pribadi, model adalah sesuatu yang menggambarkan adanya pola berpikir. Model secara sederhana dapat diartikan sebagai deskriptif yang menjelaskan suatu konsep (2009:86). Jadi, model merupakan konsep dasar yang digunakan sebagai acuan dalam melakukan atau membuat sesuatu.

\section{Pengertian Pembelajaran}

Pembelajaran merupakan proses untuk membantu peserta didik agar dapat belajar dengan baik. Menurut Degeng (Wena, 2014:2), pembelajaran berarti upaya membelajarkan siswa. Dengan kata lain, pembelajaran merupakan suatu hal yang bersifat eksternal dan sengaja dirancang untuk mendukung terjadinya proses belajar internal dalam diri individu.

\section{Pengertian Model Pembelajaran}

Secara umum model pembelajaran merupakan pola pembelajaran yang tergambar dari awal sampai akhir yang disajikan secara khas oleh guru untuk mencapai kompetensi/tujuan pembelajaran yang diharapkan. Astarani menyatakan bahwa model pembelajaran adalah seluruh rangkaian penyajian materi ajar yang meliputi segala aspek sebelum sedang dan sesudah pembelajaran dilakukan guru serta segala fasilitas yang terkait yang digunakan secara langsung atau tidak langsung dalam proses belajar mengajar (2011:1). 
Pengertian Model Pembelajaran Silent Demonstration

Suprijono menyatakan bahwa model pembelajaran aktif silent demonstration merupakan model pembelajaran yang membantu siswa untuk menemukan jawaban dengan mengkontruksi sendiri pemikirannya berdasarkan demonstrasi bisu/percobaan dengan penjelasan seminim mungkin (2010:12).

Karakteristik Model Pembelajaran Silent Demonstration

Menurut Sudjana, metode pembelajaran silent demonstration akan tepat digunakan apabila:

1. Kegiatan pembelajaran ditekankan pada pembinaan, perluasan atau pengembangan pengetahuan, sikap, dan keterampilan peserta didik.

2. Pendidik bermaksud untuk membelajarkan peserta didik melalui peragaan proses dan/atau peragaan hasil tertentu.

3. Program pembelajaran berkaitan dengan transformasi pengalaman praktis.

4. Program pembelajaran berkaitan dengan pengetahuan praktis dan keterampilan tertentu.

5. Pengorganisasian peserta didik terbatas sehingga setiap kegiatan dilakukan paling banyak oleh sekitar 20 orang.

6. Terdapat kebutuhan belajar dan sumber-sumber pendukung yang berkaitan dengan penggunaan metode silent demonstration.

7. Metode silent demonstration dapat digunakan sebagai pendukung metode-metode lain, seperti metode ceramah bervariasi, perancangan program, dan pemecahan masalah kritis(2010:134).

Langkah-langkah Model Pembelajaran Silent Demonstration

Menurut Suprijono, langkah-langkah model pembelajaran silent demonstration adalah sebagai berikut:
1. Tentukan prosedur atau langkahlangkah yang akan diajarkan kepada siswa.

2. Mintalah kepada siswa untuk memerhatikan anda untuk mengerjakan prosedur tertentu. Lakukan dengan penjelasan atau komentar yang seminim mungkin. Tugas anda di sini adalah memberikan gambaran visual tentang prosedur tersebut. Jangan terlalu berharap siswa akan banyak mengingat apa yang anda kerjakan. Dalam kesempatan ini anda hanya dituntut untuk membangun kesiapan belajar siswa.

3. Bentuk siswa menjadi pasanganpasangan. Demonstrasikan lagi bagian pertama dari prosedur, usahakan tidak terlalu banyak memberi penjelasan. Minta masingmasing pasangan untuk mendiskusikan apa yang mereka saksikan dari demonstrasi sang guru.

4. Minta beberapa orang untuk menjelaskan apa yang anda lakukan. Jika siswa masih kesulitan, ulangi lagi demonstrasi anda. Komentari observasi yang benar.

5. Akhiri dengan memberi tantangan kepada siswa untuk melakukan prosedur dari awal sampai akhir (2009: 115).

\section{Kelebihan Model Pembelajaran Silent} Demonstration

Rostinah NK (Istarani, 2011:217) mengatakan bahwa beberapa kelebihan materi pembelajaran yang didemonstrasikan antara lain :

1. Proses penerimaan siswa terhadap pembelajaran akan lebih terkesan secara mendalam sehingga membentuk suatu pengertian dengan baik dan sempurna.

2. Siswa dapat mengamati dan memperhatikan pada apa yang 
diperlihatkan guru selama pelajaran berlangsung.

3. Model pembelajaran ini sangat baik digunakan untuk mengajarkan pelajaran yang menuntut keterampilan tertentu.

\section{Kekurangan Model Pembelajaran Silent Demonstration}

Menurut Istarani, kekuranganmodel pembelajaran silent demonstrationsebagai berikut:

1. Menggunakan waktu yang relatif lama.

2. Adakalanya media yang dipraktikkan atau didemonstrasikan kurang tersedia dengan baik.

3. Topik yang dipraktikkan kurang diatur secara baik sehingga merumitkan siswa dalam mempraktikkannya.

4. Imajinasi siswa kurang terlatih dalam mempraktikkan materi yang diajarkan, karena jarang sekali guru melakukan hal ini.

5. Tidak semua siswa diberikan kesempatan untuk mempraktikkannya (2012: 218).

\section{Pengertian Kemampuan}

Pada dasarnya kemampuan sering disebut sebagai kompetensi yang artinya, sebagai suatu kecakapan yang dimiliki seseorang dalam melakukan suatu hal. Menurut Stephen P. Robin (Sakti, 2011: 69) menyatakan, "Kemampuan adalah kapasitas seorang individu untuk mengerjakan berbagai tugas dalam suatu pekerjaan". Seseorang dikatakan mampu apabila ia bisa melakukan sesuatu yang harus ia lakukan.Kemampuan menunjukkan potensi orang untuk melaksanakan tugas atau pekerjaan.

\section{Pengertian Menulis}

Menulis merupakan suatu keterampilan berbahasa yang aktif, produktif, kompleks, dan terpadu yang berupa pengungkapan dan yang diwujudkan secara tertulis. Menurut Dalman (2014:3) menyatakan bahwa menulis merupakan suatu kegiatan komunikasi berupa penyampaian pesan (informal) secara tertulis kepada pihak lain dengan menggunakan bahasa tulis sebagai alat atau medianya. Keterampilan menulis memerlukan latihan yang konsisten agar tulisan menjadi berkualitas.

\section{Tujuan Menulis}

Setiap penulis harus mengungkapkan dengan jelas tujuan penulisan yang akan digarapnya. Menurut Semi (2007: 14-21), ada beberapa tujuan orang menulis adalah (a) untuk menceritakan sesuatu, (b) untuk memberikan petunjuk atau pengarahan, (c) untuk menjelaskan sesuatu, (d) untuk meyakinkan, dan (e) untuk merangkum. Jadi, dapat disimpulkan bahwa tujuan menulis adalah menjadikan pembaca memahami dan mengerti sesuatu hal yang kita beritakan.

\section{Fungsi Menulis}

Sitorus, dkk. (2015: 26) menyatakan bahwa ada beberapa fungsi yang kita dapatkan dalam kegiatan menulis, di antaranya sebagai berikut:

1. Dengan menulis kita akan terlatih untuk berpikir secara kritis.

2. Dengan menulis kita terlatih mengutarakan pikiran dengan menggunakan kosa kata yang tepat sesuai dengan struktur dan kaidah yang berlaku dari bahasa yang kita gunakan.

3. Dengan menulis memudahkan kita untuk merasakan menikmati hubungan-hubungan, memperdalam daya tanggap atau persepsi kita memecahkan masalah-masalah yang mita hadapi, dan menyusun urutan bagi pengalaman.

4. Dengan menulis membantu kita dalam mengungkapkan pengalaman, menjelaskan pikiranpikiran kita yang sulit, dan kita dapat mengutarakannya kepada orang lain.

5. Dengan menulis kita sering menemukan apa yang sebenarnya kita pikirkan dan rasakan mengenai orang-orang lain, gagasan-gagasan, 
masalah-masalah, pendapatpendapat dan kejadian-kejadian hanya dalam pikiran saja.

\section{Manfaat Menulis}

Menulis merupakan suatu keterampilan yang memiliki manfaat. Dalam buku yang berjudul Pembinaan Kemampuan Menulis Bahasa Indonesia karya Akhadiah, dkk. (2012: 1-2), diuraikan beberapa keuntungan yang diperoleh dari kegiatan menulis, yaitu sebagai berikut:

1. Dengan menulis kita dapat lebih mengenali kemampuan dan potensi diri kita. Kita mengetahui sampai di mana pengetahuan kita tentang suatu topik. Untuk mengembangkan topik itu kita terpaksa berpikir, menggali pengetahuan dan pangalaman yang kadang tersimpan di alam sadar kita.

2. Melalui kegiatan menulis kita mengembangkan berbagai gagasan. Kita terpaksa bernalar; menghubung-hubungkan serta membandingkan fakta-fakta yang mungkin tidak pernah kita lakukan jika kita tidak menulis.

3. Kegiatan menulis memaksa kita lebih banyak menyerap, mencari, serta menguasai informasi sehubungan dengan topik yang kita tulis. Dengan demikian, kegiatan menulis memperluas wawasan baik secara teoretis maupun mengenai fakta-fakta yang berhubungan.

4. Menulis berarti mengorganisasi gagasan secara sistematik serta mengungkapkan secara tersurat. Dengan demikian, kita dapat menjelaskan permasalahan yang semula masih samar bagi diri kita sendiri.

5. Melalui tulisan, kita dapat menjadi peninjau dan penilai gagasan secara objektif.
6. Dengan menuliskan di atas kertas kita akan lebih mudah memecahkan permasalahan, yaitu dengan menganalisisnya secara tersurat, dalam konteks yang lebih konkret.

7. Tugas menulis mengenai suatu topik mendorong kita belajar secara aktif. Kita harus menjadi penemu sekaligus pemecah, bukan sekedar menjadi penyadap informasi dari orang lain.

8. Kegiatan menulis yang terencana akan membiasakan kita berpikir serta berbahasa secara tertib.

\section{Ragam dan Asas Menulis}

Menurut Finoza (2008: 238), ragam tulisan dapat didasarkan pada cara penyajian dan tujuan umum. Berdasarkan hal tersebut ragam menulis dapat dibedakan menjadi enam: Deskripsi, eksposisi, argumentasi, narasi, persuasi dan campuran/kombinasi.

Suatu paragraf yang baik harus memperhatikan kaidah-kaidah penulisan. Menurut Kosasih (2012: 5-6), ada ada beberapa hal yang harus diperhatikan dalam menyusun sebuah paragraf yang baik, antara lain sebagai berikut:

1. Ketepatan Pemilihan Kata

Tulisan yang baik pemilihan katanya harus sesuai dengan situasi dan kondisi pemakaiannya. Hal ini menyangkut hal-hal, seperti tempat, waktu, dan siapa yang menjadi sasaran tulisan yang kita buat.

2. Kelogisan

Hubungan kalimat yang satu dengan kalimat yang lainnya harus didasarkan pada penalaran atau kelogisan. Sebuah tulisan atau paragraf harus ada kesinambungan antara topik pada kalimat yang pertama dengan topik pada kalimat berikutnya.

3. Kekompakkan Hubungan Antarkalimat

Kekompakkan suatu paragraf dapat dibentuk melalui penggunaan konjungsi, pengulangan kata atau frasa, pemakaian kata yang sama 
maknanya, pemakaian kata yang berhiponimi dengan tepat

4. Kesatuan Gagasan

Paragraf harus memiliki satu gagasan utama. Kalau dalam paragraf itu terdapat dua gagasan utama, gagasan-gagasan itu harus ditempatkan pada paragraf yang berbeda.

\section{Pengertian Teks Prosedur}

Kridalaksana (2011:238) dalam

Kamus Linguistik menyatakan bahwa teks adalah (1) satuan bahasa terlengkap yang bersifat abstrak, (2) deretan kalimat, kata, dan frasa yang membentuk ujaran, (3) ujaran yang dihasilkan dalam interaksi manusia. Dilihat dari tiga pengertian teks yang dikemukakan dalam Kamus Linguistik tersebut dapat dikatakan bahwa teks adalah satuan bahasa yang bisa berupa bahasa tulis dan bisa juga berupa bahasa lisan yang dihasilkan dari interaksi atau komunikasi manusia.

\section{Tujuan Teks Prosedur}

Tujuan komunikatif dari teks prosedur adalah memberikan petunjuk tentang cara melakukan sesuatu melalui tindakan-tindakan atau langkah-langkah yang urut. Jadi, dapat dikatakan tujuan menulis teks prosedur adalah untuk menunjukan atau menjelaskan bagaimana mengerjakan sesuatu dengan langkahlangkah yang urut sehingga pembaca makin tertarik dan semakin mengerti dengan membaca teks prosedur tersebut.

\section{Struktur Teks Prosedur}

Dalam buku kelas VIII

(Kemendikbud, 2014: 88) dijelaskan bahwa ada dua struktur teks prosedur yaitu:

1. Bagian tujuan berisi tujuan dari pembuatan teks hingga hasil akhir yang ingin dicapai (dapat juga berupa judul).

2. Bagian langkah-langkah berisi tata cara yang akan ditempuh untuk mencapai tujuan. Langkah-langkah ini sifatnya cenderung kaku dan sebaiknya tidak diubah urutannya, agar hasil bisa dipastikan.

\section{Macam-macam Teks Prosedur}

1. Teks prosedur sederhana adalah suatu teks yang di buat untuk melakukan suatu kejadian hanya dengan menggunakan sedikit tahapan yang urutannya bisa di ubah-ubah.

2. Teks prosedur kompleks adalah suatu teks prosedur yang terdiri atas banyaknya tahap atau langkahlangkah yang setiap tahapan atau langkah-langkahnya berjenjang pada sublangkah dan urutan langkahlangkahnya teratur dan tidak dapat di ubah-ubahsehingga mudah dipahami oleh pembaca.

3. Protokol adalah suatu prosedur yang langkah-langkahnya tidak terlalu ketat dan rumit dan mudah dipahami.

\section{Ciri-ciri Unsur Kebahasaan Teks Prosedur}

Sulistyawati dan Krisdiyanto menyatakan bahwa ciri yang menonjol dari teks prosedur adalah penjelasan tentang alat dan bahan serta urutan langkah-langkah mengerjakan suatu kegiatan. Secara rinci ciri-ciri teks prosedur adalah sebagai berikut:

1. Teks prosedur menggunakan kalimat perintah (imperative) untuk menyampaikan ungkapan atau saran atau larangan, seperti hindari!, campurlah!, aduklah!, dan tiriskan!.

2. Teks prosedur menggunakan katakata yang menunjukkan urutan kegiatan, seperti pertama-tama, kedua, ketiga, kemudian, lalu, dan terakhir.

3. Teks prosedur menggunakan satuan (berat, panjang, waktu, dan sebagainya) dengan tepat dan akurat.

4. Teks prosedur mengandung kalimat dengan batasan yang pasti, seperti rebuslah sampai mendidih, gabungkan kedua ujung talinya hingga membentuk lingkaran, dan guntinglah sehingga membentuk dua bagian. 
5. Teks prosedur umumnya menggunakan kalimat pasif, seperti, ditahan, ditiup, dan ditunggu.

6. Teks prosedur menggunakan kata keterangan (cara, alat, tujuan, derajat/kuantitas, syarat, akibat), misalnya dengan, secara, menggunakan, agar, supaya, dua kali, dan secepatnya.

7. Penggunaan akhiran -kan dan -i, misalnya goyangkan, olesi, bersihkan, dan lain-lain (2014: 109).

\section{Langkah-langkah Menyusun Teks Prosedur}

Adapun langkah-langkah dalam menyusun teks prosedur, diantaranya adalah sebagai berikut:

1. Menentukan topik.

2. Mengumpulkan sumber informasi, baik itu dari media cetak maupun elektronik, atau anda dapat melakukan wawancara kepada pakar atau orang yang memahami topik yang akan anda tulis.

3. Mengembangkan informasi yang telah dikumpulkan ke dalam langkah-langkah yang saling berkaitan.

4. Menyusun teks prosedur secara utuh.

\section{Hal-hal yang Diperhatikan dalam} Menyusun Teks Prosedur

Adapun syarat yang harus diperhatikan dalam menyusun sebuah teks prosedur adalah sebagai berikut:

1. Jelas, artinya tidak membingungkan dan mudah diikuti, pilihan kata/bahasa yang digunakan dan keruntutan uraian, dan menggunakan nomor urut untuk membedakan langkah yang satu, langkah yang lain, menggunakan istilah-istilah yang lazim, dan petunjuk dapat dilengkapi dengan unsur gambar.

2. Logis, yang meliputi urutan penjelasan harus logis, tidak tumpang tindih dalam melakukan/membuat sesuatu dan urutan penjelasan harus berhubungan secara praktis dan logis sehingga tidak akan menimbulkan salah langkah.

3. Singkat, yang meliputi hanya mencantumkan hal-hal yang penting saja, dan kata-kata/kalimat yang digunakan tidak ada yang berulang, tetapi sudah mencukupi keseluruhannya proses yang dibutuhkan, dan penggunaaan katakata yang fungsinya untuk memperindah petunjuk tidak diperlukan.

\section{METODE PENELITIAN}

Penelitian ini dilakukan di kelas VIII SMP Budi Murni 3 Medan tahun pelajran 2016/2017. Subjek penelitian berjumah 60 orang siswa. Metode yang digunakan adalah metode eksperimen.

Desain penelitian adalah Static Group Comparison. Di dalam desain ini, kelompok dibagi menjadi dua; separuh diberi pelatihan (eksperimen) dan separuh lagi tidak diberi pelatihan (kelompok kontrol). Desain penelitian ini hanya melakukan postes yang kemudian dibandingkan untuk menentukan pengaruh tretment.

Metode yang digunakan dalam penelitian adalah metode eksperimen. Rumus yang digunakan adalah uji " $\mathrm{t}$ " sebagai berikut:

$t_{o}=\frac{M_{1}-M_{2}}{S E_{M x-M y}}$

\section{HASIL PENELITIAN DAN PEMBAHASAN \\ Hasil Penelitian}

Dari pengolahan data, diperoleh nilai rata-rata kelas eksperimen $=78.63$, standar deviasi $=9.78$, dan termasuk pada kategori sangat baik, baik dan cukup, yakni kategori sangat baik $=30 \%$, kategori baik $=$ $37 \%$ dan kategori cukup $=33 \%$. Nilai ratarata kelas kontrol $=61.8$, standar deviasi 10.00, dan termasuk pada kategori baik, cukup, dan kurang, yakni kategori baik = $7 \%$, kategori cukup $=67 \%$, dan kurang $=$ $27 \%$. Berdasarkan uji normalitas, data kelas 
eksperimen dan kontrol dinyatakan berdistribusi normal. Setelah $t_{\text {hitung }}$ diketahui, selanjutnya dikonsultasikan dengan harga $t$ tabel dengan derajat kebebasan $(\mathrm{dk})=(\mathrm{N} 1+\mathrm{N} 2)-\mathrm{k}=(30+30)-$ $2=58$ dan taraf kesalahan $\alpha=5 \%$. Harga $\mathrm{t} d \mathrm{k}$ $=58$ dengan harga 2.01. karena $t_{\text {hitung }}$ diperoleh lebih besar dari $t_{\text {tabelyaitu }} 6,27>$ 2.01 maka hipotesis nihil $\left(\mathrm{H}_{0}\right)$ ditolak dan hipotesis alternatif $\left(\mathrm{H}_{\mathrm{a}}\right)$ diterima. Hal ini membuktikan bahwa model pembelajaran silent demonstration berpengaruh dalam kemampuan menulis teks prosedur pada siswa.

\section{Pembahasan Hasil Temuan}

Berdasarkan hasil penelitian di atas, maka diperoleh temuan penelitian sebagai berikut:

1. Kemampuan siswa dalam menulis teks prosedur dengan menggunakan model silent demonstration tergolong dalam kategori baik dengan nilai rata-rata sebesar 78.63.

2. Kemampuan siswa dalam menulis tanpa menggunakan model silent demonstration tergolong dalam kategori cukup dengan nilai rata-rata sebesar 61.80 .

3. Berdasarkan uji $\mathrm{t}$ diperoleh $\mathrm{t}_{0}=6.27$, kemudian dikonsultasikan dengan harga tabel $\mathrm{t}$ dengan derajat kebebasan $(\mathrm{dk})=$ 30 adalah 2.01 maka hipotesis nihil (H0) ditolak dan hipotesis alternatif (Ha) diterima. Hal ini membuktikan bahwa model pembelajaran silent demonstration berpengaruh dalam kemampuan menulis teks prosedur pada siswa kelas VIII SMP Budi Murni 3 Medan tahun pelajaran 2016/2017.

Berdasarkan hasil di atas, diketahui kemampuan menulis teks prosedur dengan menggunakan model silent demonstration di kelas eksperimen memperoleh nilai ratarata sebesar 78.63 dan termasuk dalam kategori baik dengan jumlah siswa sebanyak 30 orang. Adapun kategori pencapaian kemampuan menulis teks prosedur tersebut termasuk ke dalam lima kategori yaitu kategori sangat baik sebanyak 9 siswa
(30\%), kategori baik sebanyak 11 siswa (36.7\%), kategori cukup sebanyak 10 siswa (33\%), kategori kurang baik sebanyak 1 (3\%), dan kategori tidak baik sebanyak 0 siswa $(0 \%)$ atau tidak ada.

Hasil yang diperoleh dari kemampuan menulis teks prosedur siswa tanpa menggunakan model silent demonstration yang diterapkan di kelas kontrol, nilai rata-rata sebesar 61.80 dan tergolong kategori cukup dengan jumlah siswa sebanyak 30 orang. Adapun kategori pencapaian kemampuan menulis teks prosedur termasuk ke dalam lima kategori yaitu kategori sangat baik sebanyak 0 siswa $(0 \%)$, kategori baik sebanyak 2 siswa $(6.7 \%)$, kategori cukup sebanyak 20 siswa (66.7\%), kategori kurang baik sebanyak 8 (26.7\%), dan kategori tidak baik sebanyak 0 siswa $(0 \%)$ atau tidak ada.

Sesuai dengan hasil analisis data dan temuan penelitian, dijelaskan bahwa penggunakan model silent demonstration berpengaruh signifikan terhadap pembelajaran menulis teks prosedur. Hal ini terlihat dari perolehan nilai dengan menggunakan model silent demonstration dengan rata-rata 78.63 dan nilai rata-rata tanpa menggunakan model silent demonstration 61.80 .

\section{KESIMPULAN}

Berdasarkan hasil penelitian tentang pengaruh model pembelajaran silent demonstration terhadap kemampuan menulis teks prosedur siswa kelas VIII SMP Budi Murni 3 Medan tahun pelajaran 2016/2017.

1. Kemampuan menulis teks prosedur siswa kelas VIII SMP Budi Murni 3 Medan tahun pelajaran 2016/2017 dengan menggunakan model pembelajaran silent demonstration diperoleh penyebaran 53 sampai 93 dengan nilai rata-rata 78.63 dan berada dalam kategori baik.

2. Kemampuan menulis teks prosedur siswa kelas VIII SMP Budi Murni 3 Medan tahun pelajaran 2016/2017 tanpa menggunakan model pembelajaran silent demonstration 
diperoleh penyebaran 40 sampai 80 dengan nilai rata-rata 61.80 dan berada dalam kategori cukup.

3. Hasil belajar siswa dengan menggunakan model silent demonstration berpengaruh signifikan terhadap pembelajaran menulis teks prosedur.Berdasarkan hasil uji hipotesis maka dapat disimpulkan bahwa $t_{\text {hitung }}$ diperoleh lebih besar dari $\mathrm{t}_{\text {tabel }}$ yaitu 6.27> 2.01 artinya hipotesis nihil (Ho) ditolak dan hipotesis alternatif (Ha) diterima.

\section{DAFTAR KEPUSTAKAAN}

Akhadiah, Sabarti, dkk. 2012.Pembinaan Kemampuan Menulis Bahasa Indonesia. Jakarta: Erlangga.

Arikunto, Suharsimi. 2016. Prosedur Penelitian: Suatu Pendekatan Praktik. Jakarta: Rineka Cipta.

Aryani, Hesti. 2015. "Peningkatan Keterampilan Menulis Teks Prosedur Kompleks dengan Metode Discovery Learning pada Siswa Kelas X IPS 1 SMA Negeri 1 Salaman Tahun Pelajaran 2014/2015".Jurnal Universitas Muhammadiyah Purwerejo Vol. 3 No. 31.

http://ejournal.umpwr.ac.id/index. php/surya-

bahtera/article/view/2679.

Diakses tanggal pada tanggal 04 Januari 2017.

Atmazaki.2013."Implementasi Kurikulum 2013 Mata Pelajaran Bahasa Indonesia: Pola Pikir, Pendekatan Ilmiah, Teks (Genre), dan Penilaian Otentik". Jurnal Universitas Negeri Padang ISBN: 978-602-17017-2-0.

http://ejournal.unp.ac.id/index.php /isla/article/view/3962. Diakses pada tanggal 06 Januari 2017.

Azwar, Saifuddin. 2013. Metode Penelitian. Yogyakarta: Pustaka Pelajar.

Dalman. 2014. Keterampilan Menulis. Jakarta: Rajawali Pers.
Finoza, Lamuddin. 2008. Komposisi Bahasa Indonesia. Diksi: Jakarta.

Istarani. 2011. 58 Model Pembelajaran Inovatif. Medan: Media Persada.

Kaelan. 2010. Pendidikan Pancasila. Yogyakarta: Paradigma.

Kementerian Pendidikan dan Kebudayaan. 2014. Bahasa Indonesia Wahana Pengetahuan: Buku Guru. Jakarta: Kemendikbud. . 2014. Bahasa Indonesia Wahana Pengetahuan: Buku Siswa. Jakarta: Kemendikbud.

Keraf, Goris. 2001. Komposisi. Semarang: Nusa indah.

Kosasih, E. 2012. Dasar-dasar Keterampilan Menulis. Bandung: Yrama Widya.

Kridalaksana, Harimurti. 2001. Kamus Linguistik. Jakarta: Gramedia.

Margono, S. 2010. Metodologi Penelitian Pendidikan. Jakarta: Rineka Cipta.

Ngalimun. 2012. Strategi dan Model Pembelajaran. Yogyakarta: Aswaja Pressindo.

Noor, Juliansyah. 2011. Metodologi Penelitian. Jakarta: Prenadamedia Group.

Nurgiantoro, Burhan. 2014. Penilaian Pembelajaran Bahasa Berbasis Kompetensi. Yogyakarta: BPFEYogyakarta.

Nurhemy, Try Nesia, dkk. 2011. "Penerapan Active Learning dengan Silent Demonstration untuk Meningkatkan Keterampilan Proses Sains Siswa Kelas VIII D SMP Negeri 14 Surakarta”. Jurnal Universitas Sebelas Maret Vol 3 No 3. http://jurnal.fkip.uns.ac.id/index.p $\mathrm{hp} / \mathrm{bio} /$ article/view/1454. Diakses tanggal 04 Mei 2017.

Nuruddin. 2012. Dasar-dasar Penulisan. Malang: UMM Press.

Pribadi, Benny A. 2009. Model Desain Sistem Pembelajaran. Jakarta: Dian Rakyat. 
Pusat Bahasa Depatemen Pendidikan Nasional. 2014. Kamus Besar Bahasa Indonesia (Edisi Ke-IV). Jakarta: Gramedia Pustaka Utama. Ritonga, Parlaungan. Mascahaya, dkk. 2014. Bahasa Indonesia Praktis. Medan: Bartong Jaya.

Sakti, Indra. 2011. "Korelasi Pengetahuan Alat Praktikum Fisika dengan Kemampuan Psikomotorik Siswa di SMA Negeri q Kota Bengkulu”. Jurnal Exacta, Vol. IX No.1.http://repository.unib.ac.id/5 32/1/10.\%20Indra\%20Sakti\%206 7-76.pdf. Diakses Taggal 04 Mei 2017.

Semi, Atar. 2007. Dasar-dasar Keterampilan Menulis. Bandung: Angkasa.

Siregar, Mustika Wati. "Pengaruh Model Pembelajaran Demonstrasi Bisu (Silent Demonstration) terhadap Kemampuan Menulis Cerpen Siswa Kelas X SMA Swasta Teladan Sei Rampah Tahun Pembelajaran 2012/2013”. Jurnal Universitas Negeri Medan Vol. 2 No. 2 Tahun 2013. http://jurnal.unimed.ac.id/2012/in dex.php/sasindo/article/view/653. Diakses pada tanggal 05 Januari 2017.

Sitorus, Pontas, dkk. (2015). Pengajaran Bahasa Indonesia di Perguruan Tinggi. Medan: Lembaga Kajian Ekolinguistik (LKE).

Sudijono. Pengantar Statistik Pendidikan. Jakarta: Rineka Cipta.

Sudjana. 2005. Metode Statistika. Bandung: Tarsito.

2010. Metode dan Teknik Pembelajaran Partisipan. Bandung: Falah Fundaction.

Sugiyono. 2012. Metode Penelitian kuantitatif Kualitatif dan $R \& D$. Bandung: Alfabeta.

Sujarweni, Wiratna. 2014. Metodologi Penelitian. Yogyakarta: Pustaka Baru Press.
Sulistyowati, Trisni dan Anang Krisdiyanto. 2014. Bahasa Indonesia Kebanggaan Bangsaku. Surakarta. Tiga Serangkai Pustaka Mandiri.

Suprijono, Agus. 2009. Cooperative Learning. Yogyakarta: Pustaka Pelajar.

Syarifudin. 2013. Kamus Praktis Bahasa Indonesia. Tangerang: Scientific Press.

Tampubolon, Saur. 2014. Penelitian Tindakan Kelas sebagai Pengembangan Profesi dan Keilmuan. Jakarta: Erlangga.

Tampubolon, Zuzun Maria Rezeki. 2015. "Pengaruh Media Gambar terhadap Kemampuan Menulis Teks Prosedur Kompleks Oleh Siswa Kelas X SMA Negeri 20 Medan Tahun Pelajaran 2014/2015". Medan: UNIMED (Skripsi yang tidak dipublikasikan).

Tarigan, Guntur. 2008. Menulis sebagai Keterampilan Berbahasa.Bandung: Penerbit Angkasa Bandung.

Wena, Made. 2014. Strategi Pembelajaran Inovatif Kontemporer: Suatu Tinjauan Konseptual Operasional. Jakarta: Bumi Aksara.

Mulyadi. 1997. Sistem Akuntansi. Yogyakarta: Bagian Penerbit Fakultas Ekonomi YKPN.

Zainurrahman. 2013. Menulis: Dari Teori hingga Praktik. Bandung: Alfabeta. 